\title{
Sustainability of Marine Food Resources-An Ecological and Fishery Approach
}

\author{
José-Antonio González*
}

Institute for Environmental Studies and Natural Resources (i-UNAT), University of Las Palmas de Gran Canaria, Spain

"Corresponding author: José-Antonio González, University Institute for Environmental Studies and Natural Resources (i-UNAT), University of Las Palmas de Gran Canaria, Campus de Tafira, 35017 Las Palmas de Gran Canaria;

E-mail: pepe.solea@ulpgc.es

\begin{abstract}
The present viewpoint summarizes the major threats to the sustainability of marine food resources from an applied ecological and fishery approach. Threats include unsustainable activities related to fisheries, aquaculture, urban and tourism development, marine traffic, introduced and spread of non-native species, other human industrial actions, as well as climate change, invasive alien species, and inadequate policies and legislation. This contribution still aims to identify main key elements concerned in the sustainable use of these resources; six groups are identified: (1) identification of main exploited commercial species, differentiation from other similar resources, and normalization of their common names; (2) ecosystem-based management of coastal ocean waters; (3) biodiversity, taxonomic biogeography and oceanographic forces; (4) responsible fish consumption; (5) "Mediterranean diet"; (6) fisheries biology studies, mainly with an ecosystem approach. A comparison between most-consumed native fishing products in Spanish Mediterranean and Canary Islands shows high similarity in seafood, putting in evidence the broad presence of the "Mediterranean diet" in both regions. This paper also aims to be a baseline to support and identify ongoing/further measures for conservation of associate biodiversity and main exploited commercial species. Some remarks on fisheries biology studies, as a useful tool for assessment, management and conservation of marine food resources are made; these are related to: regulations of fishing gear and fishing activity; assessments of their impact as well as of the commercial fish stocks potentiality; improvement of the statistical control of fish landings; marine protected areas; application of the ecosystem approach; and awareness of responsible fish consumption.
\end{abstract}

Received date: July 22, 2016

Accepted date: August 2, 2016

Published date: August 12, 2016

Citation: González, J.A. Sustainability of Marine Food Resources-An Ecological and Fishery Approach. (2016) J Environ Health Sci 2(3): 1- 5.

DOI: $10.15436 / 2378-6841.16 .1027$

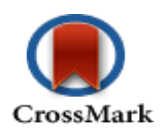

\section{Introduction}

Experts have recommended (and there are widely accepted) that nutrition should consider sustainability as a key element in their planning, and must constitute itself a priority on the agenda for climate change mitigation. Food production has indeed different impacts on the environment, such as habitat degradation and loss of biodiversity among others. Changes in diet by a combination of reducing animal products and increasing plants can not only produce benefits for human health and use of land/aquatic resources, but also can play a decisive role in the mitigation policies of global warming. For further information and bibliography, see contributions to the present Monograph.

In particular, both sustainable use of marine resources and conservation measures of the associate biodiversity are major goals on national and international policy agendas (Spalding et al., 2007).

From an applied ecological and fishery approach, the present viewpoint briefly summarizes the major threats to the sustainability of marine food resources. This contribution still aims to identify key elements concerned in the sustainable use of these resources, but also to be a baseline to support and identify ongoing/further measures for conservation of the associate biodiversity and, in particular, of the main exploited commercial marine species. 


\section{Threats as a first background}

Many human activities in both coastal and oceanic environments, as well as some natural causes have been widely found as major threats on the sustainability of marine food resources and, in particular, to biodiversity. These major threats and pressures could be summarized in the following Decalogue:

a) Illegal, unreported, and unregulated (mainly unsustainable industrial, but also artisanal in some cases) professional fisheries, including by-catch and ghost fishing, causing overexploitation of natural resources;

b) Illegal, unreported, unregulated, and generally uncontrolled (mainly unsustainable) recreational fisheries;

c) Unsustainable aquaculture based on food supplies from wild fish populations;

d) Urban and tourism development, causing alteration/loss of natural habitats and biodiversity;

e) Heavy marine traffic (including ballast water and oil platforms) and ship-strikes;

f) Introduced and spread of non-native species, linked to aquaculture, aquarium and/or pet trade among other activities;

g) Other human (mainly industrial) activities in both coastal and oceanic environments;

h) Global climate change and regional phenomena of tropicalization;

i) Invasive alien species, linked both to natural phenomena or human-caused events;

j) Inefficiency, inefficacy or absence of local/regional/global policies and ad hoc legislation.

To illustrate overfishing the case of the north western coast of Africa can be used, which is one of the most important productive and fishing areas of the world, and characterized by important fishing grounds (Arístegui et al., 2009). Fishery catches in this area reach more than 2 million tons per year. From 1950 the small-sized pelagic species represented $32 \%$ of the average catch, followed by medium-sized pelagic ones with $29 \%$, and cephalopods with a mean catch of $5 \%$. The Food and Agriculture Organization of the United Nations (FAO) estimates that more of the $40 \%$ of the fisheries in this area are currently in a senescent phase providing about $10 \%$ of catches, and the rest are in a mature phase providing about $90 \%$ of catches of small and medium pelagic species (Arístegui et al., 2009). Due to their generally elevated market value, both coastal benthic and coastal pelagic resources are very sought, showing a general decreasing trend in the catches since 1999 (FAO, 2012). They are exploited by both industrial and artisanal fleets in a multi-purpose fishery, with benthic fish species being by catch of other fisheries (FAO, 2012). Deep benthic species are secondary resources in the area and for this reason their scientific information is scarce. However, during the last decades and along with the global decline of the resources in shallow coastal waters, fishing efforts have been globally expanded to offshore areas and into deeper water (Pauly et al., 2005; Morato et al., 2006).

Many authors have recently postulated on a tropicalization process of fish assemblages in temperate biogeographic transition zones including Macaronesia (Brito et al., 2005) and some parts of the Mediterranean (Horta Costa et al., 2014), associated with global warming in many cases (Perry et al., 2005; Occhipinti-Ambrogi, 2007). A recent review accounts for this topic in temperate marine ecosystems, emphasizing that climate-driven changes in biotic interactions can profoundly alter ecological communities (Vergés et al., 2014). In this regard, during the last thirty years ichthyologists have reported on the occurrence (and sometimes establishment) of non-native marine fish species around the Canary Islands, generally arriving from subtropical/tropical nearby areas (Brito et al., 2005; Triay-Portella et al., 2015).

In response to warmer conditions, marine fishes tend to shift their distributions to higher latitudes and fish are predicted to keep shifting under climate change scenarios (Perry et al., 2005; Cheung et al., 2009). However, in the case of human-caused factors, the new distribution areas are linked to some transport vectors of non-native fish species. Human-mediated introduction and spread of non-indigenous species are considered one of the main threats to marine biodiversity and, in recent years, the degree of interest in introduced species has increased worldwide (Streftaris et al., 2005; Molnar et al., 2008).

Anthropogenic vectors of introduction of warm affinity exotic species are generally synergic with the natural range extensions and, therefore, all causes together are significantly reinforcing (for instance in the Canary Islands) the tropical/subtropical component of their littoral fish/invertebrate assemblages. The ecological impact of these non-indigenous fishes on the native fish community remains unknown, and more investigation and awareness is needed to understand these extensions or translocations prior to take environmental management measures (Triay-Portella et al., 2015; González, 2016).

For further details on present-day situation, problems and prospects for future research, as an example related with the impacts of tourism and leisure activities on marine ecosystems and their biodiversity in the Mediterranean Sea, see Bianchi \& Morri (2000) and Lloret (2010).

In the current scenario of loss of taxa and bioinvasion, increasing the knowledge about the composition of marine species that occur in different regions, understanding/predicting some faunal movements between areas (mainly of benthic habitat), and long-term monitoring is an emergency need to control and preserve biodiversity.

\section{Key elements for the sustainability as a second background}

In my opinion, the following first set of key elements is concerned in the sustainable use of the marine resources: a) identification (main distinguishing features together with an international ID code: fao-3-alfa-code) of main exploited commercial species, b) differentiation from other similar resources, and c) normalization of their common names, useful biological/socioeconomic information for their sustainable exploitation and statistics on their regional catches, among others. In this regard, the numerous and impressive contributions of FAO need to be highlighted here, particularly the compilations of the FAO Species Identification and Data Programme, for instance: Scombrids of the World; FAO Species Identification Guide for Fishery Purposes. Moreover, the FAO 
superb periodicals on: The State of World Fisheries and Aquaculture; The State of Food and Agriculture; among others.

Another key element is the ecosystem-based management of coastal ocean waters. A multi-disciplinary panel of experts established 66 Large Marine Ecosystems (LMEs) of the world and linked watersheds (Sherman et al., 2006). As an approach to the World Summit on Sustainable Development targets, LMEs were assessed with five spatio-temporal indicators of ecosystem: a) productivity, b) fish and fisheries, c) pollution and health, d) socioeconomics, and e) governance. "LMEs are relatively large areas of ocean space of approximately $200,000 \mathrm{~km}^{2}$ or greater, adjacent to the continents in coastal waters where primary productivity is generally higher than in open ocean areas." (http://www.lme.noaa.gov/). Each one of the LME is characterized by their singular bathymetry, hydrography and productivity and their ability to support marine populations, which have adapted their feeding, reproductive and growth strategies. The three first indicators are science-based and focus on the natural state of the ecosystems, socioeconomics is social science-based and concentrates on human dimensions, and the governance module was designed to adjust human behaviours towards LMEs, and improve the relationship between human society and LMEs (Wang, 2005). For instance, Spanish coastal ocean waters belong to the following ecosystem-based framework: Iberian Coastal, Mediterranean, and Canary Current, which is a major upwelling region off the coasts of Northwest Africa, encompassing from the Straits of Gibraltar to Guinea-Bissau.

A third group of key elements are biodiversity, taxonomic biogeography and oceanographic forces, as major drivers of ecological patterns. Their datasets have supported the bioregionalization of coastal and shelf areas, based on a comprehensive biogeographic system to classify the oceans. The "Marine Ecoregions of the World" is a nested hierarchical system of 12 realms, 62 provinces, and 232 ecoregions (Spalding et al., 2007). The ecoregions aim to capture generic patterns of biodiversity across habitats and taxa, with regions extending from the intertidal zone to the $200 \mathrm{~m}$ depth contour. Spanish coastal and shelf areas belong to the following biogeographic framework: South European Atlantic Shelf and Azores-Canaries-Madeira within the Lusitanian province, and Western Mediterranean and Alboran Sea within the Mediterranean Sea province, both provinces of the Temperate North Atlantic realm. The "Pelagic Provinces of the World" is a biogeographic classification of the surface pelagic waters of the world's oceans, describing 37 pelagic provinces nested into four broad realms (Spalding et al., 2012).

A fourth key element is the responsible fish consumption: sustainability focused on the consumer and trader. Change the world from consumption? Responsible fish consumption understood as an attitude of the consumer that involves making a conscious, critical and ethical use of fishery products, which is demonstrated when buying favouring the conservation of ecosystems and the sustainability of resources and extractive activity. Responsible consumption of fish can work, in the act of decision on the fish product chosen, the size/weight of the specimen, sex and reproductive phase, the capture system or production, the origin of the product and its presentation (whole or transformed), which influences the conservation of ecosystems and the sustainability of fisheries resources and artisanal fishing activity. It is up to the consumer to consider or not as responsible consumption the fact prioritizing buy fish from their native region, as a way to enhance the local fishing activity and jobs.

Lloret (2010) summarized the benefits supplied by Mediterranean marine biodiversity to human health, and highlighted the causes that are threatening them. Mediterranean Sea is a valuable source of seafood, which as component of the so-called "Mediterranean diet" has important health benefits. Also the Mediterranean benthic organisms have provided a variety of bioactive substances to treat human diseases. So the Mediterranean diet is another key element for sustainability in Mediterranean countries, including (for many reasons) the nearby Macaronesian archipelagos. It is worth noting that around $30 \%$ of littoral benthic fish and decapod crustaceans occurring around the Canaries have an Atlanto-Mediterranean biogeographic pattern, i.e. they also regularly occur in the Mediterranean (González, 2016). Based on own experience and unpublished data, a comparison between most-consumed native fishing products in Spanish Mediterranean and Canary Islands shows high similarity in (available) seafood, putting in evidence the broad presence of the "Mediterranean diet" in both regions (Table 1).

Table 1: Comparison between most-consumed native fishing products in Spanish Mediterranean and Canary Islands.

\begin{tabular}{|l|l|l|l|l|}
\hline \multirow{2}{*}{ English name } & \multirow{2}{*}{ Spanish name } & \multirow{2}{*}{ Scientific name } & \multicolumn{2}{|l|}{ Consumer appreciation / Remarks } \\
\cline { 4 - 5 } & & & Mediterranean & Canary Islands \\
\hline Bonyfishes & Peces óseos & & & \\
\hline Tunas & Atunes & Thunnus spp. & Very important & Very important \\
\hline Amberjacks & Peces limón / Medregales & Seriola spp. & Very important & Very important \\
\hline Sardine \& similar & Sardina \& similares & Clupeidae & Very important & Very important \\
\hline Anchovy & Boquerón / Longorón & Engraulis encrasicolus & Very important & Very important \\
\hline Bonitos & Bonito \& Listado & Sarda \& Katsuwonus & Important & Important \\
\hline Mackerels & Caballas / Estorninos / Verdeles & Scomber spp. & Important & Important \\
\hline Horse mackerels & Chicharros / Jureles & Trachurus spp. & Moderate & Moderate \\
\hline European hake & Merluza europea & Merluccius merluccius & Very important & Important (large sizes) \\
\hline Blue whiting & Bacaladilla & Micromesistius poutassou & Very important & Absent \\
\hline Groupers & Mero \& similares & Epinephelus \& Mycteroperca & Very important & Very important \\
\hline Wreckfish & Cherna & Polyprion americanus & Very important & Very important \\
\hline Red mullets & Salmonetes & Mullus spp. & Very important & Very important \\
\hline Porgies & Pargos, Dentones, Samas, Sargos & Sparidae & Important & Very important \\
\hline
\end{tabular}


An Ecological and Fishery Approach of Marine Food

\begin{tabular}{|c|c|c|c|c|}
\hline Scorpionfishes & Cabracho, Bocanegra \& similares & Scorpaenidae sensu lato & Important & Important \\
\hline Soles & Lenguados & Soleidae & Important & Moderate \\
\hline Forkbeards & Brótolas / Brota-Agriote & Phycis spp. & Moderate & Important \\
\hline Gurnards & Rubios \& similares & Triglidae & Moderate & Minor \\
\hline Combers & Serranos / Cabrillas & Serranidae & Moderate (fumet) & Important \\
\hline Morays & Morenas & Muraenidae & Minor & Moderate \\
\hline Mediterranean parrotfish & Vieja & Sparisoma cretense & Virtually absent & Very important \\
\hline Alfonsinos & Alfonsiños / Fulas de altura & Beryx spp. & Virtually absent & Important \\
\hline Triggerfishes \& Filefish & Peces ballesta \& Gallito verde & $\begin{array}{l}\text { Balistidae \& Stephanolepis } \\
\text { hispidus }\end{array}$ & Virtually absent & Important \\
\hline Cartilagenous fishes & Peces cartilaginosos & & & \\
\hline Smooth-hounds & Cazones / Tollos & Triakidae & Moderate & Moderate \\
\hline Skates / Rays & Rayas & Rajidae & Moderate & Very limited \\
\hline Shellfishes & Mariscos & & & \\
\hline Octopuses & Pulpos & Octopodidae & Very important & Very important \\
\hline Cuttlefishes & Sepias / Chocos & Sepiidae & Very important & Important \\
\hline Squids \& Flying squids & Calamares \& Potas & $\begin{array}{l}\text { Loliginidae \& Ommastrephi- } \\
\text { dae }\end{array}$ & Very important & Important \\
\hline Striped soldier shrimp & Camarón soldado & Plesionika edwardsii & Very important & Important \\
\hline Red \& Pink shrimps & Gamba roja / blanca \& similares & Aristeidae \& Penaeidae & Very important & Minor/virtually absent \\
\hline Norway lobster & Cigala & Nephrops norvegicus & Very important & Virtually absent \\
\hline Spiny \& locust lobsters & Langostas \& Cigarras de mar & $\begin{array}{l}\text { Palinurus elephas \& } \\
\text { Scyllarides latus }\end{array}$ & Moderate & Moderate \\
\hline Shore \& littoral crabs & Cangrejos de orilla \& littorales & Brachyura (several families) & Moderate (fumet) & Moderate \\
\hline Deep-sea red crabs & Cangrejos rojos de profundidad & Geryonidae & Moderate (fumet) & Very limited \\
\hline Limpets & Lapas & Patella spp. & Minor & Moderate \\
\hline \multicolumn{5}{|c|}{ both regions fish is fried mainly in olive oil, not butter, or traditional recipes are used. } \\
\hline
\end{tabular}

At last, another key element for the marine food sustainability is the life history traits or biological parameters provided by Fisheries Biology studies, mainly those based on an Ecosystem Approach (EA). These aspects are treated below, aiming to be a baseline to support/identify ongoing/further measures for assessment, management and conservation of the regional/global main exploited commercial species/resources and their associate biodiversity.

\section{Remarks on Fisheries Biology as a tool for management and conservation}

Some remarks or considerations on Fisheries Biology studies, as a useful tool for the assessment, management and conservation of marine food resources are made in this section.

From an ecological and fishery approach of the Fisheries Biology, the 1987 United Nations definition of sustainability, as a part of the concept "sustainable development", could be adapted as follows: sustainable development is responsible development and management of fishery resources that meets the needs of the present without compromising the ability of future generations to meet their own needs. Specifically, the sustainability of the marine food resources implies the design of a plan and the implementation of measures, in order to ensure that an appropriate percentage of individuals in a population have the chance to reproduce at least once in their life cycle, protecting the parental stock capable of producing eggs and generate a number of offspring to ensure future recruitments and perpetuation of the population (González et al., 2012). Philosophically, "sustainable development" has been defined as the light of a lighthouse in the darkest of nights, or even as a useful utopia.

In my opinion, the sustainability of a fishery resource can be achieved through the implementation of a Decalogue of regulatory measures and management actions such as:

a) Rational regulation of fishing gear authorized together with an efficient/effective control of the fishing effort (in both professional and recreational fisheries).

b) Fishing regulations on the basis of seasonal/zonal closures for the extractive activity, consistent with the spawning season and reproductive pattern of main commercial fish species.

c) Fishing regulations on the basis of an adequate Minimum Landing Size for each one of the target fish species, consistent with their biological size at first maturity, other life history traits and the state of the population being exploited (González et al., 2012).

d) Complementary fishing regulations on the basis of an adequate Maximum Landing Size for each one of the target species, consistent with their relative reproductive potential.

e) Periodical assessment of the effects/impact on fish populations by the various fishing gear involved. 
f) Periodical assessment of the potentiality of commercial fish stocks: estimation of their Maximum Sustainable Yield and, if the case, regulation on the basis of catch limits.

g) Improvement of the statistical and technical control of landings on fish markets.

h) Development of a strategic effective net of marine reserves or marine protected areas, as an efficient tool for fisheries management.

i) Application of the ecosystem approach (https:/www.cbd.int/ecosystem/), as a "strategy for the integrated management of land, water and living resources that promotes conservation and sustainable use in an equitable way", recognizing that humans with their cultural diversity are an integral component of ecosystems. Fisheries management is the management of people, not fish. The EA would help to reach the objectives of The Convention on Biological Diversity (https://www.cbd.int/ecosystem/). It is based on the application of appropriate scientific methodologies focused on levels of biological organization.

j) Increasing the awareness of responsible fish consumption, even addressed to the children and young people.

Acknowledgement: To my colleagues of the Expert Meeting 2016 on Food, Community Nutrition and Sustainability, developed at Gran Canaria, Canary Islands, Spain, 8 - 9 April 2016. Prof. Dr. Serra-Majem has significantly collaborated in this work.

\section{References}

1. Arístegui, J., Barton, E.D., Álvarez-Salgado, X.A., et al. Sub-regional ecosystem variability in the Canary Current upwelling. (2009) Prog Oceanogr 83(1-4): 33-48.

2. Bianchi, C.N., Morri, C. Marine Biodiversity of the Mediterranean Sea: Situation, Problems and Prospects for Future Research. (2000) Mar Poll Bull 40(5): 367-376.

3. Brito, A.H., Falcón, J.M.T., Herrera, R. Sobre la tropicalización reciente de la ictiofauna litoral de las islas Canarias y su relación con cambios ambientales y actividades antrópicas. (2005) Vieraea 33: 515-525.

4. Cheung, W.W.L., Lam, V.W.Y., Sarmiento, J.L., et al. Projecting global marine biodiversity impacts under climate change scenarios. (2009) Fish Fisheries 10(3): 235-251.

5. FAO. Report of the FAO/CECAF Working Group on the Assessment of Demersal Resources - Subgroup North. (2012) CECAF/ ECAF Series: 302.

6. González, J.A. Brachyuran crabs (Crustacea: Decapoda) from the Canary Islands (eastern Atlantic): checklist, zoogeographic considerations and conservation. (2016) Sci Mar 80(1): 89-102.

7. González, J.A., Pajuelo, J.G., Lorenzo, J.M., et al. Talla Mínima de Captura de peces, crustáceos y moluscos de interés pesquero en Canarias. Una propuesta científica para su conservación. (2012) Gobierno de Canarias: Las Palmas de Gran Canaria, 252 pp.

8. Horta Costa, B., Assis, J., Franco, G., et al. Tropicalization of fish assemblages in températe biogeographic transition zones. (2014) Mar Ecol Prog Ser 504: 241-252.

9. Lloret, J. Human health benefits supplied by Mediterranean marine biodiversity. (2010) Mar Poll Bull 60(10): 1640-1646.

10. Molnar, J.L., Gamboa, R.L., Revenga, C., et al.Assessing the global threat of invasive species to marine biodiversity. (2008) Front Ecol Environ 6(9): 485-492.

11. Morato, T., Watson, R., Pitcher, T.J., et al. Fishing down the deep. (2006) Fish Fisheries 7(1): 23-33.

12. Occhipinti-Ambrogi, A. Global change and marine communities: Alien species and climate change. (2007) Mar Pollut Bull 55(7-9): 342-352.

13. Pauly, D., Watson, R., Alder, J. Global trends in world fisheries: impact on marine ecosystems and food security. (2005) Philos Trans R Soc B Biol Sci 360(1453): 5-12.

14. Perry, A.L., Low, P.J., Ellis, J.R., et al. Climate change and distribution shifts in marine fishes. (2005) Science 308(5730): 19121915.

15. Sherman, K. The Large Marine Ecosystem network approach to WSSD targets. (2006) Ocean Coast Manage 49(9-10): 640-648. 16. Spalding, M.D., Fox, H.E., Allen, G.R., et al. Marine ecoregions of the world: A bioregionalization of coastal and shelf areas. (2007) Bio Sci 57(7): 573-583.

17. Spalding, M.D., Agostini, V.N., Rice, J., et al. Pelagic provinces of the world: a biogeographic classification of the world's surface pelagic waters. (2012) Ocean Coast Manage 60: 19-30.

18. Streftaris, N., Zenetos, A., Papathanassiou, E. Globalisation in marine ecosystems: the story of non-indigenous marine species across European seas. (2005) Oceanogr Mar Biol 43: 419-453.

19. Triay-Portella, R., Pajuelo, J.G., Manent, P., et al. New records of non-indigenous fishes (Perciformes and Tetraodontiformes) from the Canary Islands (north-eastern Atlantic). (2015) Cybium, Int J Ichthyol 39(3): 163-174.

20. Vergés, A., Steinberg, P.D., Hay, M.E., et al. The tropicalization of temperate marine ecosystems: climate-mediated changes in herbivory and community phase shifts. (2014) Proc Biol Sci 281(1789): 1-10.

21. Wang, H. An evaluation of the modular approach to the assessment and management of Large Marine Ecosystems. (2005) Large Marine Ecosystems 13: 335-355.

Ommega Online Publishers

Journal Title: Journal of Environment and Health Science (JEHS)

Journal Short Name: J Environ Health Sci
Journal ISSN: 2378-6841

E-mail: environmentalscience@ommegaonline.com

Website: www.ommegaonline.org 